\title{
Theoretical Calculations of the Foaming Properties of Powder Agents for the Production of Aluminium Foams
}

Iva Nová, Karel Fraňa, Jiří Machuta, Iva Nováková

Faculty of Mechanical Engineering, Technical University of Liberec, Studentská 2, 46117 Liberec, Czech Republic.

E-mail: iva.nova@tul.cz,karel.frana@tul.cz,jiri.machuta@gmail.com, iva.novakova@tul.cz

This paper presents the theoretical calculations of the foaming process of selected powder foaming agents (TiH2, $\mathrm{CaH}_{2}, \mathrm{MgH}_{2}, \mathrm{ZrH}_{2}, \mathrm{CaCO}_{3}$ and $\mathrm{MgCO}_{3}$ ) regarding the volume of gas, relative density and density of the metal foam obtained with respect to the use of a certain amount of powdered blowing agent. This work is carried out in the frame of the university project in which a small subproject is dealing with the problem of the cellular lightweight metal structures. Furthermore by calculating the diffusion of hydrogen in both solid and liquid aluminium there were found results for the duration of the anticipated action of the powdered blowing agent $(0.75,1.0,1.25$, $1.50,1.75$ and 2.0 wt. $\%$ ).

Keywords: aluminium foam, foaming agent, hydrogen, relative density, density of aluminium foams

\section{Introduction}

Cellular metal systems $[1,2]$, respectively metal foams are cellular materials characterized by a porous structure. In nature, it is, for example, the structure (bones, corals, stems of plants, tree trunks, etc.). The most important advantages of cellular systems are low density, which is ensured by cellular structure. The pores are filled with gases with the volume rate varying from 40 to $98 \%$ of the total volume of the material. Despite the low density, these materials do not lose their strength and are therefore not burdened by their own weight as other construction materials. These foams have exceptional abrasive power absorption capabilities, low thermal conductivity, relatively high gas permeability, and unusual good acoustic properties. These material properties provide a great potential for future use.

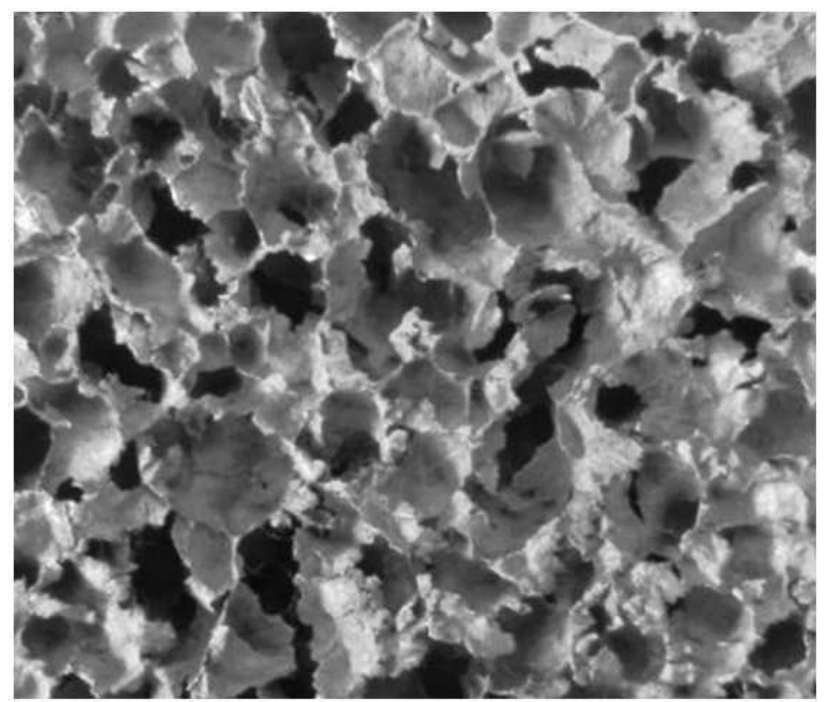

Metal foams can easily be made from aluminium, but also from zinc, lead, nickel, copper, magnesium, iron or titanium. However, foams of these metals are not as promising as ones from aluminium and its alloys. Aluminium foams are also used in the industry where only plastics have been used so far.

The production of cellular metal systems is associated with a number of problems. One problem is the difficult reproducibility of properties for completely identical components. The fault is a non-homogeneous structure, which causes quite a large dispersion of values of strength characteristics. Another issue is the high production costs of metal foams, which are hardly acceptable today. Fig. 1 shows an example of the structure created by bubbles (aluminium foams) in two magnifications $3 \mathrm{x}$ (on the left) and $7.5 \mathrm{x}$ (on the right).

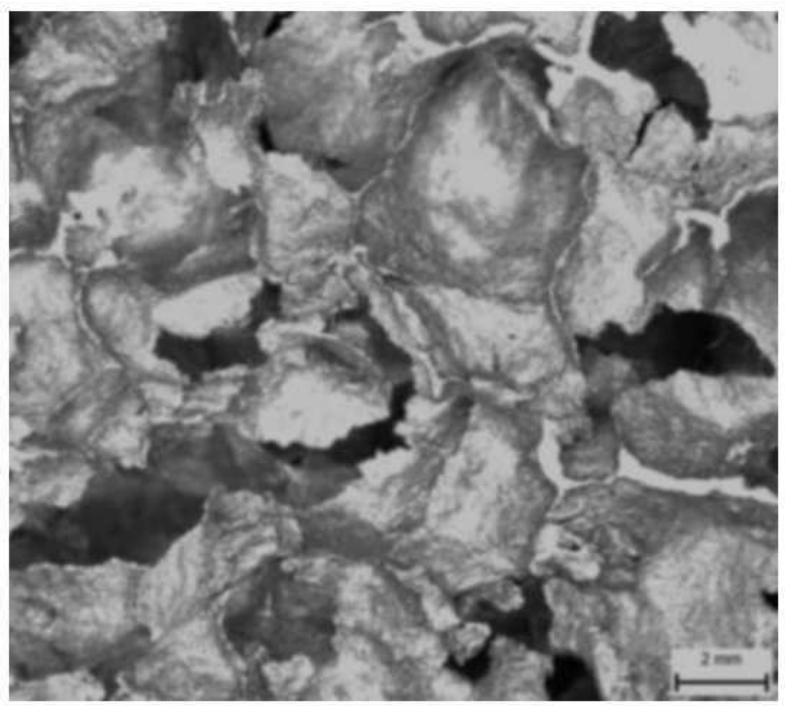

Fig. 1 Examples of the structure of aluminium created by bubbles-magnifications $3 x$ (on the left) and $7.5 x$ (on the right)

The most commonly used metal for foaming is aluminium which is also commercially marketed by several companies under the trade names (Alporas ${ }^{\circledR}$, Duocel ${ }^{\circledR}$, Metcomb ${ }^{\circledR}$, etc.) or Cymat, Alulight, AFS, ALM, Norsk-
Hydro, Gasar, which are known all over the world [3, 4]. Aluminium is also a very important construction material. Its metallurgical processing is quite demanding [18,19]. Metal cellular systems are manufactured in two basic 
ways - direct foaming of the melt by gas from an external source, or indirect gasification by means of gasifiers. The blowing agent can be applied in a metal melt or in a metal powder mixture of a blowing agent and a powder which contributes to the optimization of the metal foam production.

\section{Characteristics of foaming agents for the pro- duction of metal cellular systems}

The availability and choice of a suitable blowing agent (foaming agent) is essential for the success of the foaming process (integral foam) of the manufactured cellular metal system. In the manufacture of metal foams, the foaming agent should have the following properties:

The high equilibrium dissociation pressure, the gas pressure for the produced "foam" (foam pressure) increases with the equilibrium pressure of the foaming agent (blowing agent). The high efficiency of the blowing agent, is needed to achieve its smaller amount. It should provide rapid decomposition kinetics in synergy with the melting temperature of the alloy. The kinetics of decomposition determines the effectiveness of the blowing agent. It must not exhibit any detrimental effect on the alloy; the addition of the foaming agent to the mesh significantly must not affect the alloy.

For the production of cellular metal systems, many metal-based foaming agents are used: $\mathrm{TiH}_{2}, \mathrm{SrH}_{2}, \mathrm{MgH}_{2}$, $\mathrm{CaCO}_{3}, \mathrm{ZrH}_{2}$ [8 -16]. These agents were chemically described and tested technologically. E.g. titanium hydride, $\mathrm{TiH}_{2}$, exhibits a decomposition temperature that is close to the melting temperature of the aluminium alloys. $\mathrm{TiH}_{2}$ titanium hydride is not always suitable for the gasification process because of the too low decomposition kinetics at the melting temperatures of some aluminium alloys [17]. Sometimes for these purposes, it is preferable to use magnesium hydride $\mathrm{MgH}_{2}$. Detailed thermodynamics and decomposition kinetics of $\mathrm{MgH}_{2}$ are reported by Binks, [11]. Thermodynamics provides information at an achievable lump pressure, while the kinetics determines the appropriate time scale for decomposition of the blowing agent.

The problem of blowing agents was also studied by Matijasevic [2]. It has been concluded that aluminum foams produced on the basis of "powder melting" that form a foaming agent usually have uneven cells, which can lead to lower mechanical properties of these cellular systems. It has been found [5] that the expansion potential of the foams and the uniformity of cell size distribution is improved and that the individual cell walls are smoother and less corrugated when the foam is blown with pretreated $\mathrm{TiH}_{2}$.

Matijasevic [5] investigated the effect of temperature on the foaming process of aluminium. For aluminium alloys, the range between the solidus heat pump and the liquid temperature for $\mathrm{Al}$ alloys from which "foams" are produced $[6,7]$ is important. According to [5], the relationship between the melting point of the aluminium alloy and the maximum hydrogen release temperatures of $\mathrm{TiH}_{2}$ and a pure $\mathrm{Al}$ precursor containing this $\mathrm{TiH}_{2}$.

Moreover, there are many factors that influence the development of aluminium foam. The basis is the use of a suitable foaming agent which releases the gas at the correct temperature to ensure its high efficiency at formation of gas bubbles and uniform foam porosity. It has been found that the onset of foam is delayed by pre-treatment of the manufacturing process. The point of circumstances can be a delay of up to 45 seconds, which corresponds to a temperature difference of $45 \mathrm{~K}$.

For blowing agents and foaming metals, the volume of released gas can be generally determined from the foaming agent used. This can be calculated on the basis of the state equation of the gases (1), [20]. It is necessary to know how much of blowing agent is necessary to use for a certain amount of metal.

$$
\begin{aligned}
& p \cdot V=n \cdot R \cdot T \\
& p \cdot V=\frac{m}{M} \cdot R \cdot T
\end{aligned}
$$

It is also possible to express in equation (2) the volume of gas released by heating the foaming agent $\left[\mathrm{m}^{3}\right]$ :

$$
\mathbf{V}=\frac{\mathbf{m}}{\mathbf{M}} \cdot \frac{\mathbf{R} \cdot \mathbf{T}}{\mathbf{p}}
$$

Where: $p$ is the normal pressure $p=101325[\mathrm{~Pa}], \mathrm{V}$ is the gas volume $\left[\mathrm{m}^{3}\right], \mathrm{n}$ is the amount of substance of gas [mol], $\mathrm{R}$ is the universal gas constant $\mathrm{R}=8.314\left[\mathrm{~J} \cdot \mathrm{K}^{-}\right.$ $\left.{ }^{1} \cdot \mathrm{mol}^{-1}\right], \mathrm{T}$ is the temperature, $\mathrm{m}$ is weight of blowing (foaming) agent $[\mathrm{g}]$ and $\mathrm{M}$ is molecular weight of blowing agent $\left[\mathrm{g} \cdot \mathrm{mol}^{-1}\right]$.

Further, the relative density of the foamed metal system can be determined by Eq.[1]:

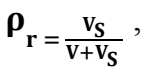

Where $\mathrm{V}_{\mathrm{S}}$ is volume of solids metal $\left[\mathrm{m}^{3}\right] ; \mathrm{V}$ is volume of gas released by heating the blowing agent $\left[\mathrm{m}^{3}\right]$.

The solid state aluminum is calculated on the basis of the known physical equation:

$$
\mathbf{V}=\frac{\mathbf{m}}{\rho}
$$

Where: $m$ is weight foamed (blowed) metal $[\mathrm{kg}] ; \rho$ aluminium density in solid state $\left[\mathrm{kg} \cdot \mathrm{m}^{3}\right]$.

In the calculation, it is often thought that for $1 \mathrm{~kg}$ of aluminium 0.5 wt. $\%$ to 1.0 weght $\%$ blowing agent is used. In our paper, the calculation was performed for the quantity of the blowing agent up to $2.0 \mathrm{wt}$. \%.

\section{Calculation of relative density of aluminum foams using $1 \mathrm{~kg}$ of aluminum and a certain amount of foaming agent based on theoreti- cal knowledge}

For theoretical calculations of foaming effects, resp. relative density and density of the aluminium foam foaming agents were used: $\mathrm{TiH}_{2}, \mathrm{SrH}_{2}, \mathrm{MgH}_{2}, \mathrm{ZrH}_{2}, \mathrm{MgCO}_{3}$ a $\mathrm{CaCO}_{3}$. The calculation of the gaseous effect can be usually expressed per kilogram of aluminium. To determine the maximum volume of released gas, equations (1), (2) (3), (4) and (5) must be adopted. The results of the calculations are given from Table 1 to Table 6 . 
Tab. 1 Theoretical calculations of the foaming action of titanium hydride in $1 \mathrm{~kg}$ of aluminium

\begin{tabular}{|c|c|c|c|c|c|c|}
\hline $\begin{array}{c}\text { Name } \\
\text { Blowing Agent }\end{array}$ & $\begin{array}{l}\text { Foamed } \\
\text { Metal }\end{array}$ & $\begin{array}{c}\text { Blowing } \\
\text { Agent } \\
\text { [wt. \%] }\end{array}$ & $\begin{array}{c}\text { Volume of } \\
\text { gas V } \\
{\left[\mathbf{m}^{3}\right]}\end{array}$ & $\begin{array}{c}\text { Volume of } \\
\text { solids metal } \\
V_{S}\left[\mathbf{m}^{3}\right]\end{array}$ & $\begin{array}{c}\text { Relative den- } \\
\text { sity } \\
\text { pr [1] }\end{array}$ & $\begin{array}{c}\text { Density } \\
\rho \\
{\left[\mathrm{g} \cdot \mathrm{cm}^{-3}\right]}\end{array}$ \\
\hline \multirow{7}{*}{$\begin{array}{l}\text { Titanium hydride } \\
\qquad\left(\mathrm{TiH}_{2}\right)\end{array}$} & \multirow{7}{*}{ Aluminium } & 0.50 & 0.0077 & \multirow{7}{*}{$3.70 \cdot 10^{-4}$} & 0.0460 & 0.124 \\
\hline & & 0.75 & 0.0115 & & 0.0312 & 0.084 \\
\hline & & 1.00 & 0.0153 & & 0.0236 & 0.064 \\
\hline & & 1.25 & 0.0192 & & 0.0189 & 0.051 \\
\hline & & 1.50 & 0.0230 & & 0.0158 & 0.043 \\
\hline & & 1.75 & 0.0268 & & 0.0136 & 0.037 \\
\hline & & 2.00 & 0.0307 & & 0.0119 & 0.032 \\
\hline
\end{tabular}

Tab. 2 Theoretical calculations of the blowing action of calcium hydride in $1 \mathrm{~kg}$ of aluminium

\begin{tabular}{|c|c|c|c|c|c|c|}
\hline $\begin{array}{c}\text { Name } \\
\text { Blowing Agent }\end{array}$ & $\begin{array}{l}\text { Foamed } \\
\text { Metal }\end{array}$ & $\begin{array}{c}\text { Blowing } \\
\text { Agent } \\
\text { [wt. } \% \text { ] }\end{array}$ & $\begin{array}{c}\text { Volume of } \\
\text { gas V } \\
{\left[\mathrm{m}^{3}\right]}\end{array}$ & $\begin{array}{c}\text { Volume of } \\
\text { solids metal } \\
V_{S}\left[\mathbf{m}^{3}\right]\end{array}$ & $\begin{array}{c}\text { Relative den- } \\
\text { sity } \\
\operatorname{\rho r}[1]\end{array}$ & $\begin{array}{c}\text { Density } \\
\rho \\
{\left[\mathrm{g} \cdot \mathrm{cm}^{-3}\right]}\end{array}$ \\
\hline \multirow{7}{*}{$\begin{array}{l}\text { Calcium hydride } \\
\qquad\left(\mathrm{CaH}_{2}\right)\end{array}$} & \multirow{7}{*}{ Aluminium } & 0.50 & 0.0091 & \multirow{7}{*}{$3.70 \cdot 10^{-4}$} & 0.0391 & 0.106 \\
\hline & & 0.75 & 0.0136 & & 0.0265 & 0.072 \\
\hline & & 1.00 & 0.0182 & & 0.0199 & 0.053 \\
\hline & & 1.25 & 0.0227 & & 0.0160 & 0.043 \\
\hline & & 1.50 & 0.0273 & & 0.0134 & 0.036 \\
\hline & & 1.75 & 0.0318 & & 0.0115 & 0.031 \\
\hline & & 2.00 & 0.0364 & & 0.0101 & 0.027 \\
\hline
\end{tabular}

Tab. 3 Theoretical calculations of the foam hydration effect of magnesium hydride in $1 \mathrm{~kg}$ of aluminium

\begin{tabular}{|c|c|c|c|c|c|c|}
\hline $\begin{array}{c}\text { Name } \\
\text { Blowing Agent }\end{array}$ & $\begin{array}{c}\text { Foamed } \\
\text { Metal }\end{array}$ & $\begin{array}{c}\text { Blowing } \\
\text { Agent } \\
\text { [wt. \%] }\end{array}$ & $\begin{array}{c}\text { Volume of } \\
\text { gas } \mathbf{V} \\
{\left[\mathbf{m}^{3}\right]}\end{array}$ & $\begin{array}{c}\text { Volume of } \\
\text { solids metal } \\
\text { Vs }\left[\mathbf{m}^{3}\right]\end{array}$ & $\begin{array}{c}\text { Relative den- } \\
\text { sity } \\
\rho_{r}[1]\end{array}$ & $\begin{array}{c}\text { Density } \\
\rho \\
{\left[\mathrm{g} \cdot \mathrm{cm}^{-3}\right]}\end{array}$ \\
\hline \multirow{7}{*}{$\begin{array}{l}\text { Magnesium hyd- } \\
\text { ride }\left(\mathrm{MgH}_{2}\right)\end{array}$} & \multirow{7}{*}{ Aluminium } & 0.50 & 0.0145 & \multirow{7}{*}{$3.70 \cdot 10^{-4}$} & 0.0248 & 0.067 \\
\hline & & 0.75 & 0.0218 & & 0.0170 & 0.046 \\
\hline & & 1.00 & 0.0291 & & 0.0126 & 0.034 \\
\hline & & 1.25 & 0.0363 & & 0.0101 & 0.027 \\
\hline & & 1.50 & 0.0436 & & 0.0078 & 0.021 \\
\hline & & 1.75 & 0.0509 & & 0.0072 & 0.019 \\
\hline & & 2.00 & 0.0582 & & 0.0063 & 0.017 \\
\hline
\end{tabular}

Tab. 4 Theoretical calculations of the blowing action of zirconium hydride in $1 \mathrm{~kg}$ of aluminium

\begin{tabular}{|c|c|c|c|c|c|c|}
\hline $\begin{array}{c}\text { Name } \\
\text { Blowing Agent }\end{array}$ & $\begin{array}{l}\text { Foamed } \\
\text { Metal }\end{array}$ & $\begin{array}{c}\text { Blowing Agent } \\
\text { [wt. \%] }\end{array}$ & $\begin{array}{c}\text { Volume of gas } \\
\mathbf{V} \\
{\left[\mathbf{m}^{3}\right]}\end{array}$ & $\begin{array}{c}\text { Volume of } \\
\text { solids metal } \\
\text { Vs }\left[\mathbf{m}^{3}\right]\end{array}$ & $\begin{array}{c}\text { Relative den- } \\
\text { sity } \\
\rho \mathrm{r} \\
{[1]} \\
\end{array}$ & $\begin{array}{c}\text { Density } \\
\rho \\
{\left[\mathrm{g} \cdot \mathrm{cm}^{-3}\right]}\end{array}$ \\
\hline \multirow{7}{*}{$\begin{array}{l}\text { Zirconium hydride } \\
\qquad\left(\mathrm{ZrH}_{2}\right)\end{array}$} & \multirow{7}{*}{ Aluminium } & 0.50 & 0.0041 & \multirow{7}{*}{$3.70 \cdot 10^{-4}$} & 0.0827 & 0.220 \\
\hline & & 0.75 & 0.0062 & & 0.0567 & 0.150 \\
\hline & & 1.00 & 0.0082 & & 0.0431 & 0.012 \\
\hline & & 1.25 & 0.0103 & & 0.0348 & 0.094 \\
\hline & & 1.50 & 0.0123 & & 0.0292 & 0.078 \\
\hline & & 1.75 & 0.0144 & & 0.0251 & 0.067 \\
\hline & & 2.00 & 0.0164 & & 0.0220 & 0.059 \\
\hline
\end{tabular}

Tab. 5 Theoretical calculations of the foaming effect of carbon dioxide obtained by decomposition of calcium carbonate in $1 \mathrm{~kg}$ of aluminium

\begin{tabular}{|c|c|c|c|c|c|c|}
\hline $\begin{array}{l}\text { Name } \\
\text { Blowing Agent }\end{array}$ & $\begin{array}{l}\text { Foamed } \\
\text { Metal }\end{array}$ & $\begin{array}{c}\text { Blowing } \\
\text { Agent } \\
\text { [wt. \%] }\end{array}$ & $\begin{array}{c}\text { Volume of gas } \\
\mathbf{V} \\
{\left[\mathbf{m}^{3}\right]} \\
\end{array}$ & $\begin{array}{c}\text { Volume of } \\
\text { solids metal } \\
V_{S}\left[\mathbf{m}^{3}\right] \\
\end{array}$ & $\begin{array}{c}\text { Relative den- } \\
\text { sity } \\
\operatorname{\rho r}[1]\end{array}$ & $\begin{array}{c}\text { Density } \\
\rho \\
{\left[\mathrm{g} \cdot \mathrm{cm}^{-3}\right]}\end{array}$ \\
\hline \multirow{7}{*}{$\begin{array}{c}\text { Calcium car- } \\
\text { bonate }\left(\mathrm{CaCO}_{3}\right)\end{array}$} & \multirow{7}{*}{ Aluminium } & 0.50 & 0.0038 & \multirow{7}{*}{$3.70 \cdot 10^{-4}$} & 0.0882 & 0.238 \\
\hline & & 0.75 & 0.0057 & & 0.0606 & 0.164 \\
\hline & & 1.00 & 0.0076 & & 0.0461 & 0.124 \\
\hline & & 1.25 & 0.0096 & & 0.0373 & 0.101 \\
\hline & & 1.50 & 0.0115 & & 0.0312 & 0.084 \\
\hline & & 1.75 & 0.0134 & & 0.0269 & 0.072 \\
\hline & & 2.00 & 0.0530 & & 0.0236 & 0.064 \\
\hline
\end{tabular}


Tab. 6 Theoretical calculations of blowing agent of the magnesium carbonate in $1 \mathrm{~kg}$ of aluminium

\begin{tabular}{|c|c|c|c|c|c|c|}
\hline $\begin{array}{c}\text { Name } \\
\text { Blowing Agent }\end{array}$ & $\begin{array}{l}\text { Foamed } \\
\text { Metal }\end{array}$ & $\begin{array}{c}\text { Blowing } \\
\text { Agent } \\
\text { [wt. \%] }\end{array}$ & $\begin{array}{c}\text { Volume of } \\
\text { gas V } \\
{\left[\mathbf{m}^{3}\right]}\end{array}$ & $\begin{array}{c}\text { Volume of } \\
\text { solids metal } \\
\text { V }\left[\mathbf{m}^{3}\right]\end{array}$ & $\begin{array}{l}\text { Relative den- } \\
\text { sity } \\
\rho_{\mathrm{r}}[1]\end{array}$ & $\begin{array}{c}\text { Density } \\
\rho \\
{\left[\mathrm{g} \cdot \mathrm{cm}^{-3}\right]}\end{array}$ \\
\hline \multirow{7}{*}{$\begin{array}{l}\text { Magnesium car- } \\
\text { bonate }\left(\mathrm{MgCO}_{3}\right)\end{array}$} & \multirow{7}{*}{ Aluminium } & 0.50 & 0.0045 & \multirow{7}{*}{$3.70 \cdot 10^{-4}$} & 0.0754 & 0.204 \\
\hline & & 0.75 & 0.0068 & & 0.0515 & 0.139 \\
\hline & & 1.00 & 0.0091 & & 0.0391 & 0.106 \\
\hline & & 1.25 & 0.0114 & & 0.0316 & 0.085 \\
\hline & & 1.50 & 0.0136 & & 0.0264 & 0.071 \\
\hline & & 1.75 & 0.0159 & & 0.0228 & 0.062 \\
\hline & & 2.00 & 0.0182 & & 0.0199 & 0.054 \\
\hline
\end{tabular}

Fig. 2 shows the amount of gas volume depending on the amount of blowing agent $\left(\mathrm{TiH}_{2}, \mathrm{SrH}_{2}, \mathrm{MgH}_{2}, \mathrm{ZrH}_{2}\right.$, $\mathrm{MgCO}_{3}$ and $\mathrm{CaCO}_{3}$ ). Fig. 3 and 4 illuminate a dependence of relative density $\rho_{\mathrm{r}}$ and density $\rho$ on the amount of the respective foaming agent $\left(\mathrm{TiH}_{2}, \mathrm{SrH}_{2}, \mathrm{MgH}_{2}, \mathrm{ZrH}_{2}\right.$, $\mathrm{MgCO}_{3}$ and $\mathrm{CaCO}_{3}$ ) in $1 \mathrm{~kg}$ of aluminium.

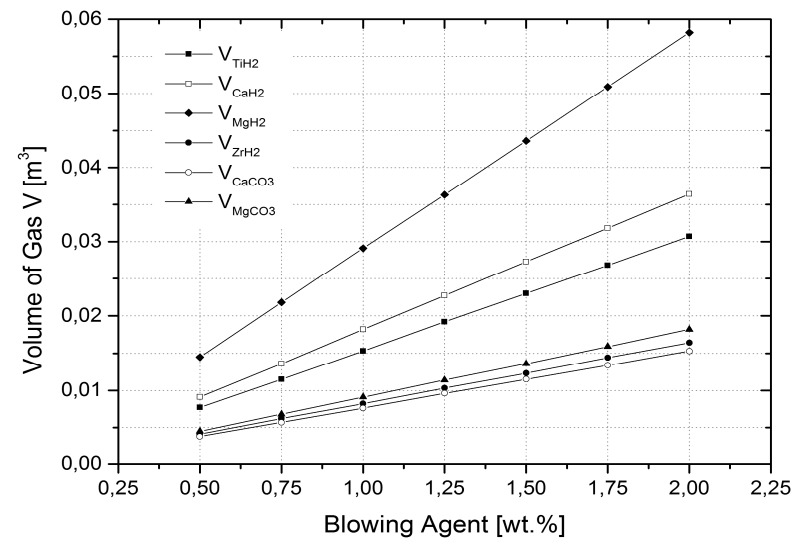

Fig. 2 Dependence of the amount of released volume gas on the amount of blowing agent

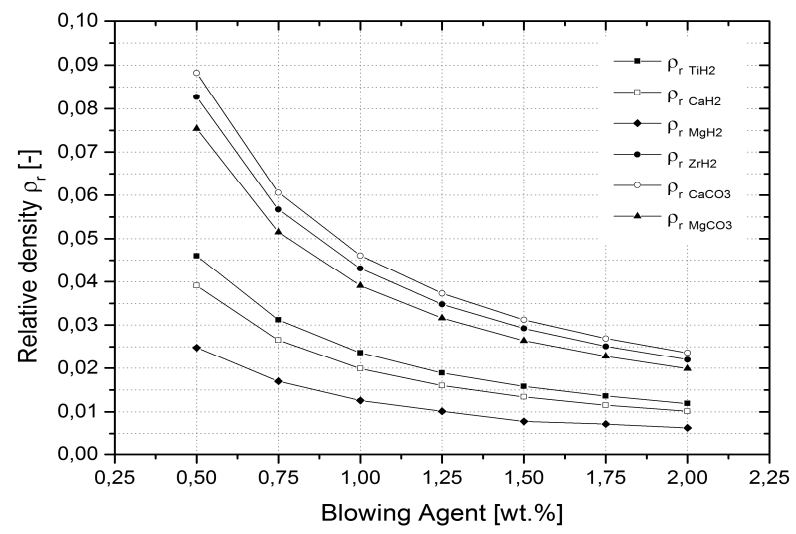

Fig. 3 Dependence of the relative density of the aluminium foam on the amount of blowing agent

In the case of this paper only a theoretical assumption was made to predict the behaviour of the foaming agent. The released gas expressed in $\mathrm{V}\left[\mathrm{m}^{3}\right]$ by heating the foaming agent is depending on the type of the used foaming agent, for hydrides $\mathrm{TiH}_{2}, \mathrm{MgH}_{2}, \mathrm{CaH}_{2}, \mathrm{ZrH}_{2}$ it is hydrogen and for carbonates $\mathrm{CaCO}_{3}, \mathrm{MgCO}_{3}$ etc. it is carbon dioxide.

When the blowing agent is heated to the appropriate temperature, other important processes occur in the production of metallic "foams". It is the decomposition of the blowing agent to form the gaseous component, the diffusion of the gaseous component, its diffusion and dissolution, the formation of heterogeneous bubbles in metal melts. However, titanium hydride is most commonly used for aluminium foams.

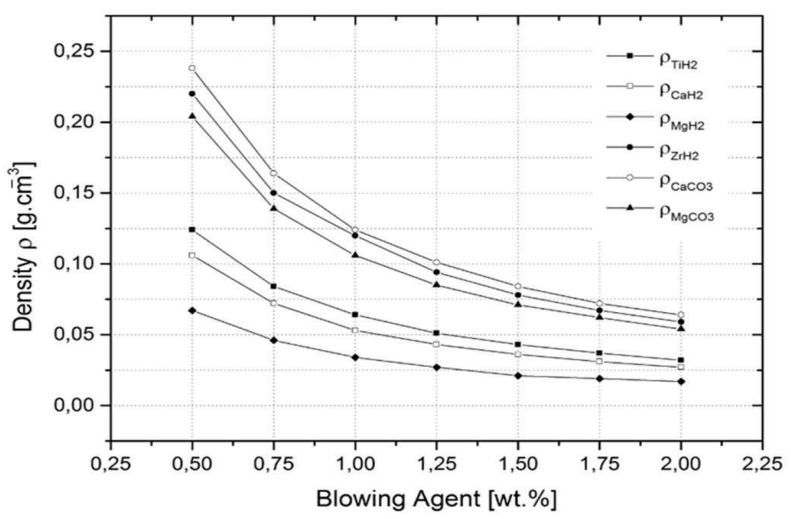

Fig. 4 Dependence of the density of the aluminium foam on the amount of blowing agent

\section{Conclusion}

This paper was focused on the theoretical calculations of the behavior of selected blowing agents, for the production of metal cellular systems, respectively aluminum "foams". By the theoretical calculations, it is clear that the biggest development of gases demonstrates $\mathrm{MgH}_{2}$ blowing agent. At using a blowing agent, $2 \mathrm{wt} \% \%$ there is the calculated volume of released gas of $0.0582\left[\mathrm{~m}^{3}\right]$. At using a blowing agent, $0.5 \mathrm{wt}$. \% gas volume was calculated to be $0.0145\left[\mathrm{~m}^{3}\right]$.

On the other hand, the lowest volume of gases exhibited $\mathrm{CaCO}_{3}$ blowing agent. At using a blowing agent, 2 wt. \% there is the calculated volume of released gas of $0.0530\left[\mathrm{~m}^{3}\right]$. At using a blowing agent, 0.5 wt. \% gas volume was $0.0038\left[\mathrm{~m}^{3}\right]$. According to practical experience of the production of aluminium "foams", the titanium hydride is mostly used. According to the used technology the content can vary from 0.5 to 1 . wt. \%. The thermal decomposition of hydrides generates hydrogen, which is the basic blowing agent.

Furthermore, based on the calculations and the application of physical relationships, the relative density of the aluminium foam $\left(\rho_{r}\right)$ and the density of the aluminium foam $(\rho)$ were determined with respect to the density of the aluminium in the solid state and the appropriate foaming agent. It is evident by theoretical calculations, the most preferred foaming agent $\mathrm{MgH}_{2}$ is leading to the 
smallest density of aluminium foam.

In the practice of producing aluminium foams, the foaming agent $\mathrm{TiH}_{2}$ with content of 0.5 to $1.0 \mathrm{wt}$. \% is commonly used. For example, for the foaming agent contenting 0.5 wt. $\% \mathrm{TiH}_{2}$ is the density $\rho_{\mathrm{r}}=0.0460$ and it corresponds to the aluminium foam density of 0.124 $\left[\mathrm{g} . \mathrm{cm}^{-3}\right]$. The densities of the produced "foam" are also dependent on the production technology. Density values starting from 0.20 to $0.25\left[\mathrm{~g} . \mathrm{cm}^{-3}\right]$ (produced by the $\mathrm{Al}$ poras method) or from 0.30 to $0.40\left[\mathrm{~g} . \mathrm{cm}^{-3}\right]$ is used according to [1], [3].

As can be seen from the above-mentioned aluminium foam density $(\rho)$ tables, theoretical calculations show that higher blowing occurred with a higher blowing agent content . For example, using 0.5 wt. $\%$ of $\mathrm{TiH}_{2}$ at first glance means that half of the quantity, i.e. $2.5 \mathrm{~g}$ of $\mathrm{TiH}_{2}$ powder, is not involved in forming the foam. However, the difference may be due to two factors. The first factor is the fact that the ideal reaction temperature is at $933 \mathrm{~K}$ (i.e. $660^{\circ} \mathrm{C}$ ) at which the aluminium melting point does not occur. As the second factor can be hydrogen lost to the environment from the pressure conditions such as the surface of the foam, for example, to rupture the wall of the cell.

\section{Acknowledgement}

This work was supported by the Ministry of Education, Youth and Sports of the Czech Republic and the European Union - European Structural and Investment Funds in the frames of Operational Programme Research, Development and Education - project Hybrid Materials for Hierarchical Structures (HyHi, Reg. No. CZ.02.1.01/0.0/0.0/16_019/0000843).

\section{References}

[1] ASHBY, M.F. EVANS, A.G.. FLECK, N.A. GIBSON, L.J HUTCHINSON J.W. WADLEY, H.N.G. (2000). Metal Foams: A Design Guide. Copyright by Butterworth-Heinemann.

[2] BANHART, J. ASHBY, M.F. FLECK, N.A. (2001). Cellular Metals and Metal Foaming Technology (MIT Verlag, Bremen).

[3] BANHART, G. (2013). Light Metal Foams - History of Innovation and Technological Challenges. Advanced Engineering Materials, No 3, pp. 82 111.

[4] KÖRNER, C. (2008). Integral Foam Molding of Light Metals. Technology Metal Foams Physic and Foam Simulation. Springer.

[5] MATIJASEVIC, B. BANHART, J. (2006) Improvement of aluminium foam technology by tailoring of blowing agent. Scripta Materrialia. Vol. 54, Iss. 4, February, pp. $503-508$.

[6] DAVIES, J.R. (1993). Aluminum and aluminum alloys ASM International, Materials Park.
[7] KAMMER, C. (1995). Aluminium taschen buch, Vol.1, Aluminium verlag, Düsseldorf.

[8] MATIJASEVIC, B. BANHART, J, FIECHTER, S. GÖRKE, O. WANDERKA, N. (2006). Modification of titanium hydride for improved aluminium foam manufacture. Acta Mater, submitted for publication.

[9] KOIZUMI, T. et al. (2011). Foaming Agents for Powder Metallurgy Production of Aluminium Foam. Materials Transactions, Vol. 52, No 4 pp. 728 to 733.

[10] WEAST, R. C. et al. (1978). CRC Handbook of Chemistry and Physics (59 th ed.). West Palm Beach, FL: CRC Press. p. B-133. ISBN 0-84930549-8.

[11] BINKS, B.P. (2002). Particles as surfactants similarities and differences. Current Opinion in Colloid \& Interface Science, 7. pp. 21-41.

[12] DEGISCHER, H.P. KRISZT, B. (2002). Handbook of Cellular Metals. WILEY-VCH.

[13] GERGELYAND, V. CLYNE, T.W. (2000). The FORMGRIP Process: Foaming of Reinforced Metals by Gas Release in Precursor. Advanced Engineering Materials, 2, pp. 175-178.

[14] GERGELY, V. CURRAN, D.C. CLYNE, T.W. (2003). The FOAMCARP process: foaming of aluminium MMCs by the chalk-aluminium reaction in precursors. Composites Science and Technology, 63, pp. 2301-2310.

[15] GUI, M.C. WANG, D.B.. WU, J.J. YUAN, G.J. LI, C. G. (2000) Deformation and damping behaviors of foamed Al-Si-SiCp composite. Materials Science and Engineering A,286, pp. 282-288.

[16] HASHIMOTO, Y. OHASHI, H. (1997). Droplet dynamics using the lattice-gas method. International Journal of Modern Physics C 8, pp. 977983.

[17] IBRAHIM, A.H. (2005)Effect of material and processing parameters on the morphology of aluminium foams produced by the PM route. PhD Thesis, University of Erlangen Nürnberg.

[18] MÜLLER, M. (2017). Effects of Aluminium Microparticles and Surface Treatment of $\mathrm{AlCu} 4 \mathrm{Mg}$ on Mechanical Properties of Adhesive Bond Strength In: Manufacturing Technology. Vol. 17, No. 1, pp. 66 - 71, ISBN 1213-2489.

[19] LIPINSKI, T. (2017). Analysis of Mechanical Properties of AlSi9Mg Alloy with Al, Ti and B In: Manufacturing Technology. Vol. 17, No. 5, pp. 761 - 766, ISBN 1213-2489.

[20] KALOUSEK, J. et al. (1990). Fyzikální chemie metalurgických procesü. (Physical chemistry of metallurgical processes). $1^{\text {st }}$ Ed. Technical University of Liberec (in Czech, Europe). 